\title{
PENGANTAR MENGENAI TEORI MARXIS TENTANG HUKUM
}

\author{
Oleh: \\ Endra Wijaya \\ Fakultas Hukum Universitas Pancasila Jakarta
}

\begin{abstract}
The opinion of Karl Marx becomes the inspiration for the appearance of the critical philosophy in the field of economics, social, politic and law. The spirit is to criticize the capitalism system that assumed of negative effect for the human life. When those opinion is came into the law, it bring the criticism to attendance of law in capitalist society. In capitalist society, law is not a free value, it's not neutral character and always related with the economic factor and also existing politics.
\end{abstract}

Kata Kunci : teori marxis dan sistem kapitalisme

\section{A. Pendahuluan}

Tulisan ini berupaya untuk memaparkan sedikit hal tentang hukum dari sudut pandang (perspektif) marxis. Oleh karena itu, tulisan ini lebih tepat didudukkan sebagai tulisan pengantar untuk membuka pemahaman mengenai teori marxis tentang hukum.

Yang patut mendapatkan perhatian pertama-tama ketika membicarakan masalah hukum dari perspektif marxis adalah, bahwa Karl Marx sendiri tidak pernah menghasilkan suatu karya yang dapat disebut sebagai "teori tentang hukum" yang utuh. ${ }^{1}$ Marx sendiri lebih tepat dikatakan sebagai seorang pemikir, filsuf, sekaligus aktivis di bidang ekonomi dan politik. ${ }^{2}$ Upaya untuk merancang secara lebih lengkap dan menyeluruh teori hukum dalam wilayah pemikiran marxis dilakukan oleh para pengikut teori Marx (para marxis).

Setidaknya terdapat 2 (dua) alasan yang dapat diajukan untuk menjawab pertanyaan "Apa perlunya mempelajari atau mengetahui tema hukum dalam lingkup pemikiran marxis?

Alasan pertama adalah untuk memperluas atau memperkaya pemahaman mengenai teori hukum itu sendiri. Terdapat kecenderungan dalam kegiatan (proses) pembelajaran ilmu hukum, bahwa masalah hukum

\footnotetext{
1 Alan Hunt, 2000, "Marxist Theory of Law", dalam Dennis Patterson ed., A Companion to Philosophy of Law and Legal Theory, Massachusetts: Blackwell Publishers Ltd, hlm. 356.

2 Ken Budha Kusumandaru, 2003, Karl Marx, Revolusi, dan Sosialisme, Yogyakarta: Insist Press, hlm. 52.
}

itu dilihat dari sudut pandang yang legal positivism ${ }^{3}$, hukum dilihat sebagai sesuatu yang bebas nilai atau tidak terkait sama sekali dengan faktor sosial dan kepentingan politik. Kritik terhadap sudut pandang seperti itu sudah banyak dilontarkan oleh para ahli hukum, misalnya seperti yang dilakukan oleh Satjipto Rahardjo melalui gagasan "Hukum Progresif"-nya atau juga oleh Roberto Unger serta Duncan Kennedy dengan Critical Legal Studies-nya (CLS).

Kritik-kritik tersebut pada intinya berpendapat bahwa hukum tidak bisa dilepaskan dari faktor-faktor yang ada di dalam masyarakat, seperti faktor nilai, moral, etika, ekonomi, bahkan politik. Literatur yang memuat kritik tadi sudah cukup banyak disebarluaskan, tetapi penulis masih melihat adanya kekurangan, yaitu terutama kritik yang membahas teori keterkaitan antara hukum dengan aktivitas ekonomi dan politik.

Kalaupun ada upaya yang telah memperkenalkan teori "hukum adalah politik", seperti melalui beberapa tulisan yang mengangkat pemikiran CLS, menurut penulis upaya itu masih juga belum cukup. Perlu dipahami, bahwa CLS memiliki akar pemikiran pada tradisi kritis yang dikembangkan oleh para

\footnotetext{
3 Qodri Azizy, "Menggagas IImu Hukum Indonesia", dalam Qodri Azizy, et al., 2006, Menggagas Hukum Progresif Indonesia, Yogyakarta: Pustaka Pelajar, IAIN Walisongo Semarang, dan Program Doktor Ilmu Hukum Universitas Diponegoro, hlm. vii.
} 
184 Jurnal Dinamika Hukum

Vol. 8 No. 3 September 2008

neomarxis. ${ }^{4}$ Jadi cukup wajar apabila tulisan teori marxis tentang hukum diperkenalkan juga berdampingan dengan tulisan-tulisan tentang CLS. Tentu upaya seperti itu akan memberikan pemahaman yang lebih lengkap, baik bagi teori hukum pada umumnya, maupun bagi teori "hukum adalah politik" pada khususnya.

Alasan kedua adalah untuk memberikan alternatif pisau analisis dalam memahami fenomena ketidakberdayaan hukum dalam memberikan rasa keadilan di masyarakat. Satjipto menyebutkan bahwa telah terjadi proses bekerjanya hukum yang justru "kontraproduktif". Satjipto bahkan juga menyebutkan bahwa "Hukum yang membawa panji-panji keteraturan dan ketertiban, misalnya, ternyata dapat menimbulkan suasana yang sebaliknya. la tidak hanya bersifat ordegenik, melainkan juga kriminogenik." 5

Keadaan hukum seperti tersebut di atas tidak dapat dipecahkan apabila hanya bersandar pada analisis hukum yang positivis (positivisme hukum). Positivisme hukum menghendaki dilepasnya unsur nilai, moral, etika, sosial, dan politik dari sistem hukum. Positivisme hukum juga melihat hukum semata-mata dalam bentuk formalnya, ${ }^{6}$ maka kemudian yang terjadi adalah reduksi terhadap proses hukum, yaitu semata-mata hanya sebagai "proses peraturan."7 Positivisme hukum akan menjawab masalah kemacetan hukum dalam menciptakan keadilan dengan kembali melakukan proses pembentukan peraturan yang baru. "Banjir" peraturanpun akhirnya terjadi, tidak peduli apakah per-

\footnotetext{
${ }^{4}$ FX. Adji Samekto, 2005, Studi Hukum Kritis: Kritik terhadap Hukum Modern, Bandung: PT. Citra Aditya Bakti, hlm. 35 dan 56. Lihat juga Otje Salman dan Anton F. Susanto, 2004, Teori Hukum: Mengingat, Mengumpulkan dan Membuka Kembali, Bandung: Refika Aditama, hlm. 124.

5 Satjipto Rahardjo (a), 2007, Biarkan Hukum Mengalir: Catatan Kritis tentang Pergulatan Manusia dan Hukum, Jakarta: Kompas, hlm. 3.

6 Firman Muntaqo, 2007, "Meretas Jalan bagi Pembangunan Tipe Hukum Progresif melalui Pemahaman terhadap Peranan Mazhab Hukum Positivis dan Non-Positivis dalam Kehidupan Berhukum di Indonesia", dalam Satjipto Rahardjo (b), Membedah Hukum Progresif, Jakarta: Kompas, hlm. 162.

7 Rahardjo (a), op.cit., hlm. 17.
}

aturan-peraturan itu akan efektif di masyarakat atau tidak.

Sebagai kritik terhadap pendekatan positivisme hukum, maka yang perlu dilakukan adalah merubah sudut pandang terhadap proses hukum. Proses hukum harus dipandang sebagai proses yang melibatkan interaksi antarmanusia atau "proses perilaku", yang di dalamnya terkait pula berbagai faktor, seperti faktor nilai, moral, etika, sosial, dan politik. Manusialah yang berperan dalam proses hukum, karena peraturan tidaklah akan mempunyai arti apa-apa kalau tidak ada faktor manusia yang menjalankannya. ${ }^{8}$ Oleh karena itu, maka diperlukan pendekatan alternatif selain pendekatan yang positivis dalam menjawab permasalahan hukum di masyarakat, dan pendekatan itu sebaiknya juga ikut mempertimbangkan banyak faktor yang ada di dalam masyarakat. Pendekatan alternatif itu salah satunya adalah pendekatan marxis tentang hukum, yang menjadi pokok pembahasan dalam tulisan ini. Pendekatan marxis tentang hukum bahkan diklaim oleh salah satu pemikirnya, Evgeny Pashukanis, sebagai sesuatu yang dibangun berdasarkan kenyataan sosial. $^{9}$

Sesuai dengan judul yang dipilih, maka yang menjadi pokok pembahasan dalam tulisan ini adalah mengenai teori marxis tentang hukum. Sebagai tulisan pengantar, maka cukup tepat apabila pembahasan dilakukan secara deskriptif, dengan hanya memaparkan secara umum beberapa pokok pemikiran yang ada di dalam teori marxis tentang hukum.

\section{B. Pembahasan}

Dalam literatur-literatur teori hukum yang telah dipublikasikan, terutama yang ditulis dalam bahasa Indonesia, masih sedikit sekali ditemui pembahasan yang memadai mengenai teori marxis tentang hukum. Jika ada, teori marxis tentang hukum itu pun masih terbatas pada hanya salah satu pendekatan yang ada

\footnotetext{
8 Satjipto Rahardjo (c), 1980, Hukum dan Masyarakat, Bandung: Angkasa, hlm. 69.

9 Evgeny Pashukanis, "The General Theory of Law and Marxism" <http://www. marxists.org/archive/pashukanis/1924/law/>. Diakses pada 22 Juli 2008.
} 
dalam teori marxis tentang hukum. Pendekatan yang lazim dijumpai adalah pendekatan "struktur dasar (bawah) dan struktur atas (base-superstructure)". ${ }^{10}$ Padahal dalam teori marxis tentang hukum masih terdapat beberapa pendekatan lainnya yang digunakan dalam membahas masalah hukum.

Menurut Alan Hunt, terdapat beberapa tema pokok yang dijelaskan oleh para pemikir marxis mengenai hakikat hukum, yaitu: ${ }^{11}$

1. Hukum tidak dapat menghindar atau tidak dapat melepaskan dirinya dari politik, atau bahkan dapat dikatakan, bahwa hukum itu adalah salah satu bentuk (perwujudan) dari politik.

2. Hukum dan negara memiliki hubungan yang dekat. Hukum memperlihatkan sifatnya yang "relatif otonom" dari negara.

3. Hukum memberikan pengaruh, mencerminkan, atau mengekspresikan kuatnya (besarnya) hubungan ekonomi yang ada.

4. Hukum selalu potensial bersifat memaksa dan memanifestasikan (mewujudkan) monopoli negara atas alat-alat pemaksa.

5. Isi dan prosedur yang terkandung dalam hukum, baik langsung maupun tidak langsung, mencerminkan kepentingan-kepentingan kelas yang berkuasa.

6. Hukum itu bersifat ideologis. Dengan demikian, hukum itu menunjukkan dan menyediakan legitimasi kepada nilai-nilai yang melekat pada (nilai-nilai milik) kelas yang berkuasa.

Tema-tema pokok di atas kemudian mengalami perkembangan lebih lanjut, sehingga melahirkan varian-varian baru dalam teori marxis tentang hukum. Setidaknya terdapat beberapa macam pendekatan terhadap hukum yang digunakan oleh para marxis sehingga

\footnotetext{
10 John Gilissen dan Frits Gorle, 2005, Sejarah Hukum: Suatu Pengantar, Bandung: Refika Aditama, hlm. 97 dan 127-128; Meuwissen, 2008, Tentang Pengembanan Hukum, Ilmu Hukum, Teori Hukum dan Filsafat Hukum, diterjemahkan oleh B. Arief Sidharta, Bandung: Refika Aditama, hlm. 72-74; dan Theo Huijbers, 2003, Filsafat Hukum dalam Lintasan Sejarah, Yogyakarta: Kanisius, $\mathrm{hlm}$. 112, tetapi pada hlm. 171-172-nya sudah menyinggung sedikit pendekatan "determinisme yang lebih lunak".

${ }^{11}$ Hunt, op.cit., hlm. 355.
}

mereka menghasilkan tema-tema pokok hakikat hukum di atas.

Pertama, pendekatan "struktur dasar (bawah) dan struktur atas (base-superstructure)". Pendekatan ini meletakkan hukum pada struktur atas, dan struktur atas ini merefleksikan apa yang menjadi struktur dasarnya, yaitu hubungan produksi kehidupan material (faktor ekonomi). ${ }^{12}$

Konsep base-superstructure mendeskripsikan masyarakat yang ada di dunia ini terbagi ke dalam 2 (dua) bagian, yaitu: struktur dasar (bawah, basestructure) dan struktur atas (superstructure). Dalam pembagian seperti itu, faktor ekonomi diletakkan pada struktur dasar, sedangkan hal-hal lainnya, seperti sistem sosial, hukum, politik, agama, seni dan ilmu pengetahuan diletakkan pada struktur atas. Segala proses yang terjadi pada struktur atas akan dipengaruhi oleh struktur dasar. ${ }^{13}$ Dalam kalimatnya Marx, "[adalah] cara produksi kehidupan material [yang] mengkondisikan proses kehidupan sosial, politik, dan spiritual pada umumnya".

Konsep base-superstructure memiliki akar pada "teori materialisme historis (the materialistic conception of history)" dari Marx, yaitu bahwa: "Semua gerakan politik, sosial, intelektual dan etis dalam sejarah dideterminasi oleh cara-cara dengan apa masyarakat mengorganisasi lembaga-lembaga sosial mereka dalam hal melaksanakan aktivitas-aktivitas produksi, pertukaran, distribusi dan konsumsi barang-barang. Setiap perkembangan historis penting pada dasarnya merupakan hasil perubahan-perubahan dalam cara bagaimana salah satu di antara aktivitasaktivitas ekonomis tersebut dilaksanakan. Hal tersebut pada pokoknya merupakan penafsiran sejarah secara ekonomis".

Ringkasnya, materialisme historis mengandung pemahaman bahwa perkembangan organisasi atau aktivitas sosial lainnya yang ada dalam masyarakat ditentukan oleh faktor

\footnotetext{
12 Ibid, hlm. 358.

${ }^{13}$ Ernest Mandel, 2006, Tesis-Tesis Pokok Marxisme, diterjemahkan oleh Ign. Mahendra, Yogyakarta: Resist Book, hlm. 90.
} 
ekonomi. Karena ditentukan oleh faktor ekonomi seperti itu, maka pendekatan ini disebut juga dengan pendekatan "determinisme ekonomi" atau sering disebut juga dengan "ekonomisme". Determinisme ekonomi merupakan salah satu ciri khas marxisme klasik (marxisme ortodoks).

Determinisme ekonomi sudah banyak mendapatkan kritik. Para pengkritik determinisme ekonomi menganggap bahwa determinisme ekonomi tidak lain adalah reduksionisme, dan gagal memandang keberagaman. Salah satu di antara pengkritik itu adalah seorang marxis, Louis Althusser. Dia bahkan mengusulkan "otonomi relatif" superstruktur tanpa mengabaikan keberadaan struktur dasar, dan menilai adanya hubungan timbal balik antara superstruktur dengan struktur dasarnya. ${ }^{14}$

Kedua, pendekatan "determinisme yang lebih lunak". Pendekatan determinisme yang lebih lunak ini memandang bahwa faktor ekonomi akan menentukan "pada akhirnya" perkembangan organisasi atau aktivitas sosial lainnya yang ada dalam masyarakat. ${ }^{15}$

Apabila dikaitkan dengan proses pembentukkan hukum, misalnya, maka pendekatan determinisme yang lebih lunak tidak akan langsung menyatakan bahwa karakter dan isi dari hukum itu pasti ditentukan hanya oleh faktor ekonomi (struktur dasar). Dalam proses pembentukkan hukum, maka segala faktor yang ada, seperti faktor politik, agama, adat, dan ilmu pengetahuan, bisa saling berinteraksi ikut membentuk hukum bersama-sama dengan faktor ekonomi. Jadi pendekatan determinisme yang lebih lunak ini masih menyediakan ruang bagi terjadinya proses saling mempengaruhi antarfaktor yang terdapat di struktur dasar dan struktur atas.

Proses saling mempengaruhi antarfaktor tersebutlah yang membedakan antara determinisme ekonomi yang "kuat" dengan yang "lunak". Pada pendekatan determinisme eko-

\footnotetext{
${ }^{14}$ Louis Althusser, 2004, Tentang Ideologi: Marxisme Strukturalis, Psikoanalisis, Cultural Studies [Essays on Ideology], Bandung: Jalasutra, hlm. 12.

${ }^{15}$ Hunt, op.cit., hlm. 359.
}

nomi yang kuat, yang menjadi faktor penentunya adalah faktor ekonomi, yang juga berarti bahwa faktor-faktor lain yang berada dalam struktur atas (superstructure) tidak akan mempunyai daya pengaruh sama sekali ketika berhadapan dengan faktor ekonomi.

Ketiga, adalah pendekatan yang dikembangkan oleh ahli hukum yang berasal dari Sovyet, Evgeny Pashukanis. Pashukanis melihat teori hukum sebagai sebuah permasalahan (pertanyaan) historis. Hal itu berarti, bahwa: pertama, pemahaman terhadap bentuk-bentuk hukum borjuis memerlukan sebuah pendekatan historis, karena hukum adalah hasil dari suatu tahap tertentu dari perkembangan masyarakat. Ke dua, Pashukanis melihat tugas dari teori marxis tentang hukum adalah untuk memperlihatkan (mendemostrasikan) keadaan alamiah yang bersifat sementara dari hukum. ${ }^{16}$ Hukum ada tidak lain adalah untuk melenyap.

Teori hukum dari Pashukanis, yaitu yang dikenal dengan "teori pertukaran komoditas (the commodity-exchange theory)", melihat kontrak (perjanjian) sebagai dasar dari semua bentuk hukum yang ada (contract as the foundation of all law). Kemudian menurutnya, hukum lahir (timbul) karena adanya kebutuhan akan komoditas ${ }^{17}$ dari proses produksi. Semua bentuk hukum diarahkan untuk mendukung (memperlancar) proses pertukaran komoditas yang terjadi di antara subjek-subjek yang bertindak sebagai "penjaga" dari komoditas tadi. ${ }^{18}$

Menurut Pashukanis, pertukaran komoditas, dari perspektif historis, mendahului sistem hukum yang terbentuk darinya. Hanya dengan perkembangan yang maksimal dari suatu proses produksi komoditas, maka akan terbuka pula kemungkinan bagi perkembangan bentuk-bentuk hukum. Produksi komoditas berkembang melalui perdagangan, dan hukum

\footnotetext{
${ }^{16}$ M.D.A. Freeman, 1994, Lloyd's Introduction to Jurisprudence, London: Sweet and Maxwell Ltd, hlm. 867.

17 "Komoditas, oleh karena itu, adalah produk yang diciptakan untuk dipertukarkan di pasar, berbeda dengan produk yang dibuat untuk konsumsi langsung. Setiap komoditas harus memiliki nilai guna maupun nilai tukar". Lihat Mandel, op.cit., hlm. 124.

${ }^{18}$ Freeman, op.cit., hlm. 868.
} 
tumbuh berkembang sebagaimana perdagangan tadi mengalami peningkatan. ${ }^{19}$

Dengan terus berkembangnya pertukaran komoditas tersebut, kemungkinan timbulnya sengketa akan semakin besar pula, dan sebuah sistem hukum haruslah hadir untuk mengatasi sengketa tadi. Pashukanis menyatakan, "It is disputes, conflicts of interest, which create the legal form, the legal superstructure". ${ }^{20}$

Pashukanis percaya bahwa hukum akan mencapai tahap perkembangan tertingginya di bawah sistem kapitalisme. Di bawah sistem kapitalisme, hukum yang berkembang tentunya adalah juga sistem hukum yang mendukung kepentingan kaum borjuis. ${ }^{21}$ Tetapi pada tahap selanjutnya, ketika tahap puncak masyarakat komunis tercapai, maka hukum itu akan ikut melenyap seiring dengan melenyapnya negara.

Pashukanis memang telah merancang teori marxisnya tentang hukum untuk mendukung (memenuhi) tujuan-tujuan politik kaum bolshevik. ${ }^{22}$ Misalnya, ketika kaum bolshevik dengan ideologinya menyakini bahwa negara, termasuk hukum, akan melenyap, maka teori hukum yang dirancang dan di kembangkan oleh Pashukanis pun mendukung keyakinan tadi. Pashukanis berpendapat bahwa hukum pada akhirnya akan melemah dan melenyap, serta kemudian digantikan oleh suatu bentuk sistem administrasi. Melenyapnya hukum itulah yang kemudian menjadi simpulan dari teori pertukaran komoditas yang dirancang dan dikembangkan oleh Pashukanis. ${ }^{23}$

Keempat, pendekatan yang mencoba membangun analisis mengenai hukum dengan menghubungkannya dengan ideologi. Bagaimanakah hubungan antara hukum dengan ideologi itu?

Collins, dalam karyanya Marxism and Law, mendefinisikan ideologi sebagai sekumpulan ide yang mendominasi yang timbul (lahir) dari dan dibentuk oleh praktik-praktik

\footnotetext{
19 Ibid.

${ }_{20}$ Pashukanis, loc.cit.

${ }^{21}$ Freeman, op.cit., hlm. 869.

22 Ibid., hlm. 867.

${ }^{23}$ Ibid., hlm. 870.
}

sosial dalam hubungan-hubungan produksi. Ideologi yang dominan akan muncul di antara kelas para pemilik alat-alat produksi yang secara bersama-sama memiliki pengalaman (pemahaman) dan memainkan peranan yang cenderung sama dalam hubungan-hubungan produksi. Kemudian hukum sebagai suatu bentuk peraturan bagi masyarakat, yang memang sengaja diciptakan, muncul dari dalam ideologi dominan itu. ${ }^{24}$ Konkretnya, nilai-nilai yang ada di dalam ideologi dominan kemudian ditransformasikan (diwujudkan) ke dalam bentuk peraturan-peraturan hukum. Rangkaian proses tadi membawa konsekuensi, yaitu bahwa hukum menjadi pembawa nilainilai ideologi dominan. ${ }^{25}$

Sebelum Collins, seorang marxis asal Italia yang bernama Antonio Gramsci, telah pula memberikan pendapatnya mengenai ideologi dominan dalam kaitannya dengan hegemoni. Setiap ideologi dominan selalu berusaha untuk mempererat formasi sosial, yang di dalamnya terdapat kelas-kelas sosial, agar berada di bawah kepemimpinan mereka (kelas dominan). Upaya untuk menggiring kelas sosial lainnya agar mau tunduk di bawah kepemimpinan kelas dominan itulah yang disebut dengan hegemoni, dan hukum menjadi salah satu instrumen penting dalam proses hegemoni. ${ }^{26}$ Gramsci menjelaskan bahwa hegemoni merupakan penundukkan kelas-kelas sosial dengan cara-cara yang lebih bersifat konsensus (persetujuan) daripada penindasan (paksaan). ${ }^{27}$ Kelas yang melakukan penundukkan itu adalah kelas hegemonik.

Apabila penjelasan mengenai hubungan hukum dengan ideologi dikaitkan dengan konsep base-superstructure, maka hukum ini akan hadir baik di struktur dasar maupun di struktur atas. Hukum hadir di struktur atas

\footnotetext{
${ }^{24}$ Costas Douzinas, Ronnie Warrington dan Shaun McVeigh, 1991, Postmodern Jurisprudence: The Law of Text in the Texts of Law, London: Routledge, hlm. 121.

${ }^{25}$ Hunt, op.cit., hlm. 361.

${ }^{26}$ Robert Bocock, 2007, Pengantar Komprehensif untuk Memahami Hegemoni, Bandung: Jalasutra, hlm. 27.

27 Nezar Patria dan Andi Arief, 1999, Antonio Gramsci: Negara dan Hegemoni, Yogyakarta: Pustaka Pelajar, hlm. 120-121. Lihat juga Roger Simon, 1999, GagasanGagasan Politik Gramsci, Yogyakarta: Insist dan Pustaka Pelajar, hlm. 19-22.
} 
adalah karena hukum itu sendiri muncul dari bidang ideologi, yang merupakan salah satu unsur pada struktur atas. Sedangkan hukum hadir di struktur dasar adalah karena hukum itu berfungsi mengatur dan memperlancar terjadinya proses hubungan-hubungan produksi. ${ }^{28}$

\section{Penutup}

Demikianlah pembahasan sekilas mengenai teori marxis tentang hukum. Simpulan sederhana yang dapat diambil dari pembahasan tersebut adalah, bahwa para pemikir marxis, setelah Marx, telah berupaya merancang dan mengembangkan teori hukum. Beragam pendekatan telah mereka gunakan dalam membahas hakikat hukum, dan walaupun dengan pendekatan yang beragam itu, teori hukum yang mereka hasilkan memiliki ciri khasnya tersendiri. Hal itu dapat dilihat, antara lain, pada adanya faktor-faktor ekonomi dan politik pada pendekatan mereka terhadap hukum, serta juga pada adanya muatan kritik terhadap sistem kapitalisme. Yang disebutkan terakhir, bahkan dapat dianggap sebagai sebuah semangat yang cenderung menjadi khas dalam pemikiran marxis ${ }^{29}$ yang selalu mengkritik habis-habisan sistem kapitalisme beserta pengaruhnya dalam kehidupan manusia.

Masih banyak celah kekurangan yang di harapkan dapat menjadi bahan tulisan selanjutnya mengenai teori marxis tentang hukum. Pembahasan penulis melalui tulisan kali ini belum sampai memaparkan pengaruh teori marxis tentang hukum dalam mendorong timbulnya aliran-aliran pemikiran dalam ilmu hukum, belum sampai memaparkan kritikkritik yang dilontarkan terhadap teori marxis tentang hukum, dan juga belum sampai pada bentuk-bentuk praktik teori marxis tentang hukum pada level negara. Setidaknya, 3 (tiga) hal itulah yang diharapkan dapat menjadi inspirasi bagi tulisan-tulisan berikutnya mengenai teori marxis tentang hukum. Sebuah "undang-

\footnotetext{
${ }^{28}$ Douzinas, Warrington, dan McVeigh, op.cit., hlm. 122.

29 Jonathan Wolff, 2004, Mengapa Masih Relevan Membaca Marx Hari Ini? [Why Read Marx Today?], Yogyakarta: Mata Angin, hlm. xii dan 150.
}

an" menulis bagi penulis lainnya untuk berani mencoba ikut serta memperkaya pustaka ilmu hukum di Indonesia.

\section{Daftar Pustaka}

Althusser, Louis. 2004. Tentang Ideologi: Marxisme Strukturalis, Psikoanalisis, Cultural Studies [Essays on Ideology]. Bandung: Jalasutra;

Azizy, Qodri. 2006. "Menggagas Ilmu Hukum Indonesia". Dalam Qodri Azizy, et al., Menggagas Hukum Progresif Indonesia. Yogyakarta: Pustaka Pelajar, IAIN Walisongo Semarang, dan Program Doktor IImu Hukum Universitas Diponegoro;

Bocock, Robert. 2007. Pengantar Komprehensif untuk Memahami Hegemoni. Bandung: Jalasutra;

Douzinas, Costas; Ronnie Warrington, dan Shaun McVeigh. 1991. Postmodern Jurisprudence: The Law of Text in the Texts of Law. London: Routledge;

Freeman, M.D.A. 1994. Lloyd's Introduction to Jurisprudence. London: Sweet and Maxwell Ltd;

Gilissen, John; dan Frits Gorle. 2005. Sejarah Hukum: Suatu Pengantar. Bandung: Refika Aditama;

Huijbers, Theo. 2003. Filsafat Hukum dalam Lintasan Sejarah. Yogyakarta: Kanisius;

Hunt, Alan. "Marxist Theory of Law". Dalam Dennis Patterson ed. 2000. A Companion to Philosophy of Law and Legal Theory. Massachusetts: Blackwell Publishers Ltd;

Kusumandaru, Ken Budha. 2003. Karl Marx, Revolusi, dan Sosialisme. Yogyakarta: Insist Press;

Mandel, Ernest. 2006. Tesis-Tesis Pokok Marxisme. Diterjemahkan oleh Ign. Mahendra. Yogyakarta: Resist Book;

Meuwissen. 2008. Tentang Pengembanan Hukum, Ilmu Hukum, Teori Hukum dan Filsafat Hukum. Diterjemahkan oleh B. Arief Sidharta.Bandung: Refika Aditama;

Muntaqo, Firman. "Meretas Jalan bagi Pembangunan Tipe Hukum Progresif melalui Pemahaman terhadap Peranan Mazhab Hukum Positivis dan Non-Positivis dalam Kehidupan Berhukum di Indonesia". dalam Satjipto Rahardjo. 2007. 
Membedah Hukum Progresif. Jakarta: Kompas;

Pashukanis, Evgeny. The General Theory of Law and Marxism. http://www.marxists.org/archive/pashukanis/1924/law/ >. Diakses pada 22 Juli 2008;

Patria, Nezar; dan Andi Arief. 1999. Antonio Gramsci: Negara dan Hegemoni. Yogyakarta: Pustaka Pelajar;

Salman, Otje; dan Anton F. Susanto. 2004. Teori Hukum: Mengingat, Mengumpulkan dan Membuka Kembali. Bandung: Refika Aditama;
Samekto, FX. Adji. 2005. Studi Hukum Kritis: Kritik terhadap Hukum Modern. Bandung: PT. Citra Aditya Bakti;

Simon, Roger. 1999. Gagasan-Gagasan Politik Gramsci. Yogyakarta: Insist dan Pustaka Pelajar;

Rahardjo, Satjipto. 1980. Hukum dan Masyarakat. Bandung: Angkasa;

2007. Biarkan Hukum Mengalir: Catatan Kritis tentang Pergulatan Manusia dan Hukum. Jakarta: Kompas;

Wolff, Jonathan. 2004; Mengapa Masih Relevan Membaca Marx Hari Ini? [Why Read Marx Today?]. Yogyakarta: Mata Angin. 